\title{
Inflation, Productivity, and the Total Off set Method of Calculating Damages for Lost Future Earnings
}

The principal purpose underlying tort damage awards is the compensation of the victim for his loss. ${ }^{1}$ Effecting this purpose, however, can prove difficult. Suppose that $D$, through the negligent operation of his automobile, strikes $P$, a forty-five-year-old manufacturing worker. $P$ 's injuries prove serious and he is left permanently unable to work. If a court finds $D$ liable at trial, it can calculate a portion of the award with ease by adding together the costs $P$ has already incurred, such as past medical expenses, outpatient therapy charges, damage to property, and earnings lost before trial. Calculating the remaining portion of $P$ 's award, however, entails adding together the future earnings $P$ will lose because he is unable to work. That calculation is complicated by having to predict events yet to occur. ${ }^{2}$

1 Restatement (Second) of ToRTs $§ 901$ comment a (1979). Some scholars justify damages as a vindication of society's interest in retribution, W. Prosser, HANDBOOK OF THE LAF or Torts $\S 2$, at 9-10 (4th ed. 1971), or as the proper way to deter tortious conduct, C. Grbgory, H. Kalven \& R. Epstein, Cases and Materials on Torts xxii-xxiii (3d ed. 1977); R. Posner, Economic Analysis of Law § 6.16, at 154-57 (2d ed. 1977). Perhaps tort damages do, or at least should, serve all of these functions. The justification one selects does not alter the need to assess damages accurately. Inadequate or excessive tort damage awards frustrate retribution and deterrence as much as they frustrate compensation.

Damage award calculation attempts to balance the plaintiff's right to compensation with the defendant's right to pay only for the harm he caused. This balancing can be explained in terms of each of the theoretical justifications used to support damages. The "reed to treat the defendant fairly" can be explained as a judicial unwillingness to redistribute wealth once adequate compensation has been awarded, an unwillingness to mete out more punishment than society demands in retribution, or a judicial desire to encourage only costjustified precautions. Though conceptually different from the compensation model, the deterrence and retribution models do not affect the level of compensation, and therefore this comment will not attempt to deduce differences produced by the different analytical models of torts.

2 The award should provide the victim with a sum of money that will, in fact, replace the money he would have earned had there been no disabling accident. Doca v. Marina 
To calculate a lost future earnings award, a court first must predict what the victim would have earned in his lifetime if not disabled. This first estimate ("Step I prediction") is a function of personal characteristics of the victim, such as his age, occupation, education, and actuarial probability of survival. ${ }^{3}$ Although courts

Mercante Nicaraguense, S.A., 634 F.2d 30, 39-40 (2d Cir. 1980), cert. denied, 451 U.S. 971 (1981).

3 The Step I-Step II typology, see also infra text following note 4, is a tool this comment has adopted for convenience and clarity. Although courts have to deal with these two analytically distinct issues in any prospective damage calculation, they often ignore the clear distinction. For an example of a case where this distinction was made, see Taenzler v. Burlington N., 608 F.2d 796 (8th Cir. 1979).

Two elements of the Type I determination-age and actuarial probability of survival-bear close examination. An individual's real income is not constant over his lifetime. Miller, Lifetime Income and Economic Growth, 55 AM. Econ. Rev. 834, 835 (1965). As a worker matures, he becomes proficient at his work, acquires new skills, and progresses to more responsible jobs. After a certain age, however, the worker's improvement slows, and he becomes accustomed to a particular job. In later life, due to decreased hours worked or diminishing abilities, the worker's wages may fall. Henderson, Income Over the Life Cycle: Some Problems of Estimation and Measurement, 25 Fed'N INs. Couns. 15, 22-26 (1974). These life cycle variations in income can be verified by studying an occupation at a single point in time:

Wage and Age Profile of Full-time

Manufacturing Workers in 1977

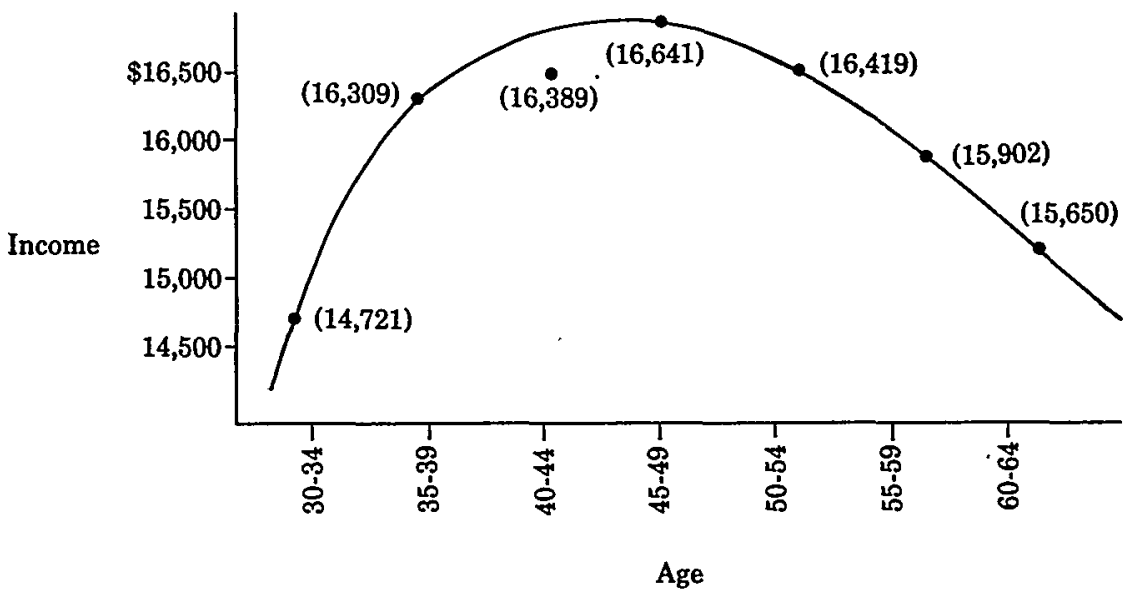

Source: U.S. Dep't of Commerce, Money Income in 1977 of Families and Persons IN THE UNITED STATES 179 (1979).

Courts differ in their use of occupation wage profiles. For example, in Feldman v. Allegheny Airlines, Inc., 524 F.2d 384 (2d Cir. 1975), aff'g 382 F. Supp. 1271 (D. Conn. 1974), the Second Circuit accepted the trial court's use of wage-profile evidence to predict the victim's expected wage increases, but the Alaska Supreme Court has allowed compensation only for wage increases keyed to seniority, State v. Guinn, 555 P.2d 530, 546 (Alaska 1976), 
can establish rules determining which characteristics may be accounted for and the evidence required to prove their effects, each Step I prediction is ultimately a question of fact and is therefore case-specific. ${ }^{\star}$

Courts have long recognized that further refinements of the Step I prediction ("Step II adjustments") are necessary because economic factors independent of the victim also affect the accuracy of the award. For example, most courts during this century have discounted the Step I prediction in recognition of the fact that money held today (i.e., the tort award) is worth more than money to be received in the future (i.e., the lost earnings for which the award compensates). ${ }^{5}$ Recently, many courts have further adjusted the Step I prediction to account for inflation. ${ }^{6}$ Noting that persistent inflation would have increased the victim's wages each year, those courts have attempted to add a corresponding amount to tort

even though it has recognized that excluding other life cycle variations may lead to undercompensating plaintiffs, id. (citing Beaulieu v. Elliott, 434 P.2d 655, 671-72 (Aleska 1967)).

The "actuarial probability of survival" is the probability that members of a certain demographic group will survive to a specified age. See S. HuEbner \& K. Black, Life InsurANCE 310-12 (7th ed. 1969). Although tort awards should be reduced by the actuarial probability of survival, courts currently calculate earnings until the expected retirement age of workers in the plaintiff's occupation, even though some workers will not survive until the expected retirement age. For example, if a plaintiff has a demographically calculated $70 \%$ probability of surviving until age 60 , then the earnings of that person at age 60 should be reduced by $30 \%$ before being added to the total award. To neglect the chance of not surviving until retirement results in systematic overcompensation of plaintiffs. Before the injury, the plaintiff's future earnings were not assured until the retirement age; the fact of injury should not improve the plaintiff's prospects. For recent mortality data, see Survival After Midlife, Statisticat Bull., July-Aug. 1977, at 2, 2 (published by Metropolitan Life Ins. Co.).

422 AM. Jur. 2D Damages § 93 (1965).

- The Supreme Court ruled in 1916 that awards for lost future earnings in certain federal causes of action must be discounted. Chesapeake \& O. Ry. v. Kelly, 241 U.S. 485, 489-91 (1916). Discounting is the method used to reflect the present value of future earnings. The present value of future earnings is the amount of money that a future claim would be worth today. The present value of a sum depends on the preference of consumers for present consumption over future consumption, on the rate of inflation (both of which are represented by the interest rate), and on the time period involved. If the interest rate is $10 \%$, the present value of $\$ 100$ to be paid one year hence is approximately $\$ 91$ because $\$ 91$ could be invested at $10 \%$ and increase in value to $\$ 100$ in one year. The present value of one dollar can be expressed algebraically as $1 /(1+r)^{t}$, where $r$ is the interest rate, and $t$ is the number of years until the payment. For a discussion of the theory of discounting, see generally Fabozzi \& Weitz, Discounting and the Determination of Economic Damages, Trial Law. Q., Spring-Summer 1976, at 39 .

- See, e.g., Doca v. Marina Mercante Nicaraguense, S.A., 634 F.2d 30, 36-40 (2d Cir. 1980), cert. denied, 451 U.S. 971 (1981). See infra notes 54-77 and accompanying text. 
awards. ${ }^{7}$

Because the economic phenomena that affect the adequacy of awards do not depend on the facts of specific cases, courts have established several general rules to account for them. ${ }^{8}$ Although virtually all courts now discount awards to present value, there is much disagreement about how, if at all, inflation or other economic factors should be taken into account. Some courts, for example, have held that the existence and extent of future inflation is a matter of speculation and therefore cannot be used in calculating tort damages. ${ }^{\circ}$ Other courts have held it reversible error to ignore the effects of inflation in calculating awards; such awards, according to these courts, would necessarily be undercompensatory. ${ }^{10}$

This comment will describe the four principal methods courts use to account for economic phenomena in lost future earnings awards and will evaluate how accurately each method would have compensated a hypothetical tort victim had the method been used to calculate an award in 1960. Contrary to the expectations of most courts, an award with no Step II adjustment would have provided the most accurate compensation. Although the method appears deceptively simple, it is consistent with economic theory: the factors that would have led one to increase awards for lost future earnings were offset almost totally by the factors that would have led one to discount awards since 1960. Because this total offset phenomenon is likely to continue, the comment concludes that courts should presume the no-adjustment method will produce an accurate award and suggests that the method should be used routinely.

' E.g., Doca, 634 F.2d at 35-37; United States v. English, 521 F.2d 63, 74-76 (9th Cir. 1975).

8 The variety of rules used by the courts is described generally infra notes $39-77$ and accompanying text. The methods are described in greater detail in Comment, Future Inflation as a Factor in the Determination of Damages, 12 U. ToL. L. REv. 369 (1981); Note, Future Inflation, Prospective Damages, and the Circuit Courts, 63 VA. L. REv. 105 (1977).

9 See, e.g., Johnson v. Penrod Drilling Co., 510 F.2d 234, 241 (5th Cir.) (en banc) (per curiam) (inflation too uncertain to require admission of specific evidence), cert. denied, 423 U.S. 839 (1975). The Fifth Circuit recently overruled Penrod in Culver v. Slater Boat Co., 688 F.2d 280 (1982). The decision, rendered en banc by members of the current Fifth and Eleventh Circuits, allows courts to use estimates of inflation in calculating damages. The court refused to mandate the use of any particular method of calculation, instead suggesting that counsel agree on damage calculation methodology before trial, wherever possible. Id. at 311.

${ }^{10}$ E.g., Kaczkowski v. Bolubasz, 491 Pa. 561, 583-84, 421 A.2d 1027, 1038-39 (1980). 


\section{Economic Factors Affecting Awards for Lost Future EARNINGS}

When a court calculates lost earnings damages, it should take into account all the factors that would have affected the plaintiff's earnings had he not been injured. The adequacy of a lost future earnings award depends upon three factors: the discount rate, ${ }^{11}$ subsequent changes in wages, and changes in the market interest rate. These in turn can be explained by inflation, labor productivity, and interest rates.

\section{A. Factors Affecting Wages}

Traditionally, courts have assumed that had a tort victim not been injured his wages would have remained constant throughout his working life. ${ }^{12}$ Wages have increased regularly since World War $\mathrm{II}^{13}$ however, primarily because of inflation and increased labor productivity.

1. Inflation. Inflation is the rise in the general level of prices. ${ }^{14}$ Wages will increase in the face of inflation when labor contracts index wages to the inflation rate or when contracts assure constant, inflation-adjusted wages. In the past, wage increases have

11 The discount rate is the rate by which courts discount tort awards to account for the time value of money. See supra note 5 and accompanying text.

12 See Note, supra note 8, at 113-19. See, e.g., Johnson v. Penrod Drilling Co., 510 F.2d 234 (5th Cir.), cert. denied, 423 U.S. 839 (1975), overruled, Culver v. Slater Boat Co., 688 F.2d 280 (1982).

1s The average manufacturing wage of a full-time worker has risen every year since 1938 and rose from $\$ 5548$ in 1960 to $\$ 16,259$ in 1979. BuREau OF ECONOMIC ANALYSIS, U.S. Dep't of Commrrce, The National Income and Product Accounts of the United States, 1929-74 Statistical Tables: A Supplement to the Survey of Current Business 210-13 (1975) [hereinafter cited as NIPA]; National Income and Product Accounts, 1976-79, SuRv. Current Bus., July 1981 Special Supp., at 54 (Table 6.9B) [hereinafter cited as NIPA Supp.].

14 Throughout the 1950 's, prices increased at an average annual rate of $2 \%$. During the 1960 's, prices increased at an annual rate of less than $2.4 \%$. Bureau of Labor Statistics, Current Labor Statistics, Monthly Lab. REv., Nov. 1970, at 76, 93 (Consumer Price Index). It is not surprising, therefore, that the judicial doctrine of the 1950's and 1960's paid little attention to the effect of inflation on tort compensation. Even economists had little to say about inflation. Economic models constructed in the mid-1950's to predict the economic future of the nation explicitly assumed inflation to be zero. See, e.g., JoINT CoMmitTEE on the Economic Report, 83d Cong., 2D Sess., Potential Economic Growth of the United States During the Next Decade 21-23 (Jt. Comm. Print 1954) [hereinafter cited as PotenTial Economic Growth]. Recent experience has shown the error of their assumptions. Throughout the 1970's the annual increase in prices ranged from $3.3 \%$ to $11.5 \%$, averaging over $7 \%$ for the decade. Bureau of Labor Statistics, Current Labor Statistics, MonTHLY LAB. REv., Dec. 1981, at 67, 87. 
followed price rises. ${ }^{15}$ Because of the tendency of wages to increase due to inflation, a tort award will be undercompensatory if it does not in some way account for inflation-induced wage increases. ${ }^{16}$

2. The Productivity of Labor. The labor productivity rate is the ratio of output to units of labor input. Changes in productivity reflect changes in real output per unit of input and indicate growth or decline in the economy. ${ }^{17}$ Productivity increases are the source of real wage increases; when workers produce more with each unit of labor, their services are worth more to their employers, who usually pay more as a result. ${ }^{18}$

Changes in the productivity of the American work force were once consistently positive, but in recent years they have fluctuated greatly, resulting in a lower net growth rate. ${ }^{19}$ Although much of this variation is due to business cycles, ${ }^{20}$ some economists have attempted to explain the fluctuations in other ways. ${ }^{21}$ If the economy returns to consistent growth in productivity, however, workers' wages will grow in real terms. Because such productivity-based increases are expected, ${ }^{22}$ a lost earnings award that does not account for real wage gains will likely be undercompensatory.

16 See L. Reynolds, Labor Economics and Labor Relations 225 (6th ed. 1974).

16 If a tort victim is given $\$ 91$ to invest at $10 \%$ for one year to yield $\$ 100$, but workers in his former occupation are earning $\$ 110$ at the end of that year because of inflation, the award is undercompensatory.

17 See generally Burgau of Labor Statistics, U.S. Dep't of Labor, Bull. No. 1910, BLS HANDBOOK OF METHODS 221-23 (1976). Although explicitly representing output per unit of labor input, the level of productivity reflects the interaction of many factors in the production process: technology, capital investment, human capital, energy, and raw materials. Id. at 221.

13 P. Samuelson, Economics 740 (10th ed. 1976) (productivity has contributed to real wage growth).

19 From 1948 through 1973, despite cyclical variations in business activity, the rate of change in productivity was always positive. In 1974, 1978, and 1979, however, the rate of productivity change was actually negative. Productivity, as measured by the change in output per hour in the private sector, increased annually by an average of $3.25 \%$ in the 1950 's, $2.9 \%$ in the 1960 's, but only by $1.56 \%$ in the 1970 's. ECONOMIC REPORT OF THE PRESIDENT 279 (1982) (Table B-41) [hereinafter cited as Economic REPoRT].

${ }^{20}$ See Okun, Potential GNP: Its Measurement and Significance, 1962 Proc. Am. StAtistical A. Bus. \& Statistics Sec. 98, 103-04.

21 See, e.g., E. Denison, Accounting for Slower Economic Growth: The United StATES IN THE 1970s (1979). Denison's study describes the decline in the rate of productivity increases observed throughout the 1970's. His model's residual term, "'advances in knowledge and not elsewhere classified," "explains over $68 \%$ of the observed decline. Probing the Productivity Puzzle, Brookings Buld., Fall 1979, at 7, 7-9 (quoting E. Denison, supra). Discussing his model's inability to properly identify the causes of the decline in the productivity growth rate, Denison has remarked, " 'What happened is, to be blunt, a mystery." "Id. at 8 (quoting interview with Edward Denison).

22 Kutscher, New Economic Projections Through 1990-An Overview, Monthly LaB. REv., Aug. 1981, at 9, 10 (predicting productivity increases of $1.4-2.6 \%$ during the 1980 's). 


\section{B. The Components of the Interest Rate}

Courts calculate the present value of funds to be received in the future by discounting the future sum by a market interest rate. ${ }^{23}$ Market interest rates are determined by risk, expected inflation, and the real interest rate. ${ }^{24}$ Because tort victims are assumed to invest their awards in virtually risk-free accounts, a court discounting awards for lost future earnings can assume the risk component equals zero; ${ }^{25}$ inflation and the real interest rate are the significant discount factors.

Market interest rates respond to expected inflation. To assure a positive return on his investment, a lender will demand an interest rate he believes will exceed inflation. If a lender expects inflation to be high during the term of a loan, he will charge a higher interest rate. Similarly, as inflationary expectations subside, interest rates will decline. Although economists disagree about how well the market interest rate reflects these adjustments for inflation, ${ }^{26}$ it is central to the theory of interest that market interest rates do vary with inflation. ${ }^{27}$

The real interest rate is the return on money after adjustment for risk and inflation; ${ }^{28}$ it is the rate lenders would charge when lending their money to a risk-free venture in an inflation-free economy. The real interest rate is not constant, but it can be treated as such because it fluctuates around an identifiable mean that is greater than zero. ${ }^{29}$ The real interest rate, inflation, and the nomi-

23 Supra note 5 and accompanying text.

24 See R. PosnzR, supra note $1, \S 6.13$, at 147.

${ }^{25} 25$ C.J.S. Damages $\$ 87(\mathrm{e})$, at 967 (1966). See O'Shea v. Riverway Towing Co., 677 F.2d 1194, 1199 (7th Cir. 1982) (assuming "ultra-safe" asset); Wentz v. T.E. Connolly, Inc., 45 Wash. 2d 127, 138, 273 P.2d 485, 492 (1954). The interest rates courts use to discount tort awards are such that tort victims need not take excessive risks in order to receive the compensation due them. Even if risk were a relevant factor, it would not greatly affect this analysis. An investor can avoid the costs of risk by diversification or by investment in lowrisk assets. R. Brealey \& S. Myers, Principles of Corporate Finance 112-14 (1981).

${ }^{28}$ Compare Fama, Interest Rates and Inflation: The Message in the Entrails, 67 AM. EcoN. REv. 487 (1977) (short-term interest rate includes accurate prediction of future inflation) with Carlson, Short-Term Interest Rates as Predictors of Inflation: Comment, 67 AM. Econ. Rev. 469 (1977) (significant information about future inflation is not reflected in the nominal short-term interest rate).

${ }^{27}$ See generally I. Fisher, The Theory of Interest 36-44 (1930); R. Posner, supra note $1, \S 6.13$, at 147; Carlson, supra note 26; Fama, supra note 26.

${ }^{28}$ The nominal interest rate is simply the rate observed in the money markets. The real interest rate is the nominal interest rate minus the rate of inflation. P. SAMUELSON, supra note 18, at 609. "Real" to economists means adjusted for inflation, and it shows what the rate would have been had inflation not occurred.

29 Carlson, supra note 26, at 470-72 (2.5\%); Gibson, Interest Rates and Inflationary Expectations: New Evidence, 62 Am. Soc. Econ. Rev. 854, 856 (1972) (2-3\%). One court, 
nal interest rate all have been positive since World War II. A tort award that is not discounted, either explicitly or implicitly, ${ }^{30}$ therefore, is overcompensatory. ${ }^{31}$

\section{Economic Comparison of Damage Compensation Methods}

This part examines how a hypothetical accident victim, $P$, would have fared with lost future earnings awards made according to four methods of calculation used by courts. ${ }^{32}$ These illustrations assume that $P$ was a forty-five-year-old manufacturing worker in 1960 , when he was awarded damages for future earnings lost due to a tort injury. ${ }^{33}$ Assuming $P$ had twenty years remaining until his retirement, ${ }^{34}$ a reasonable Step I prediction of his loss would have been twenty times his 1960 wage. Using the average manufacturing worker's wage for 1960 , that would have amounted to $\$ 110,960 .^{35}$

after analyzing the relation between interest rates and inflation, noted that the real rate approximated two percent. See Doca v. Marina Mercante Nicaraguense, S.A., 634 F.2d 30, 39 (2d Cir. 1980), cert. denied, 451 U.S. 971 (1981).

${ }^{30}$ Traditionally, courts explicitly discounted damage awards in recognition of the time value of money. See supra note 5 and accompanying text. Some modern approaches do not discount explicitly, or do so using an interest rate far less than the market interest rate. See infra notes 61-77 and accompanying text. These systems, however, discount implicitly. Rather than actually discounting an award, they refrain from increasing the award to account for other adjusting factors; this has the same effect as adjusting the award upward and then discounting it.

31 See R. PosNer, supra note $1, \S 6.13$, at 144 . See generally supra note 5 .

${ }^{32}$ One might include a fifth method, the informal offset method, used by appellate courts to affirm lower court awards that are technically faulty but comport with a rough sense of justice. The reviewing court affirms because factors that the trial court ignored offset the effects of the factors that made the award technically faulty. See, e.g., Espana v. United States, 616 F.2d 41, 44-45 (2d Cir. 1980). In Espana, the trial court neglected to consider the effect of inflation in its damage calculation. The Second Circuit refused to reverse, however, reasoning that because the five percent discount rate used by the trial court was well below the market rate, the error of not accounting for inflation was offset by the trial court's estimate of the discount rate. Id. at 44 . Because the informal offset method operates on an ad hoc basis, it does not lend itself to systematic analysis and therefore will not be included in the evaluations in this comment.

${ }^{33}$ This analysis is based on a 1960 injury for two reasons. First, the period 1960-1979 is an interesting period to study because awards of damages during this period were subjected to many unanticipated economic phenomena. Inflation became a major problem in the period, see supra note 14, interest rates varied greatly, see infra Interest Rate Column, Table 1 , and the annual productivity increase of the American work force slowed, see supra notes 19-22 and accompanying text. Second, complete and reliable data are available throughout the period, obviating the need to construct proxies for economic data.

${ }^{34} P$ 's retirement at age 65 is an arbitrary but reasonable assumption.

3s In 1960 the average manufacturing worker's wage was $\$ 5548$. NIPA, supra note 13 , at 212. The figure $\$ 110,960$ is the product of the number of years until retirement (20) and the average 1960 manufacturing worker's wage $(\$ 5548)$. This figure ignores life cycle variations in earnings and the actuarial probability of survival, consideration of which would affect proportionately all the calculations here and therefore would needlessly complicate them. 
The illustrations also assume that the court would have made a lump sum award ${ }^{36}$ premised on the theory that $P$ would invest the award in low-risk securities, ${ }^{37}$ annually withdraw the amount he would have earned had he been employed, and reinvest the remaining funds. ${ }^{38}$

\section{A. Traditional Approach}

A court evaluating P's claim in 1960 probably would have employed an approach which discounted the Step I prediction to account for the time value of money but which ignored inflation. ${ }^{39}$ Discounting theory assumes that $P$ can be awarded less money than his future loss will be, yet still be fully compensated, because he can invest the award and use the interest earned to make up the difference between the current award and the future loss. As interest rates increase, the award can be decreased, because a greater portion of $P$ 's loss will be compensated by interest rather than by the court's award.40

It is difficult to know the discount rate a 1960 court would have used; ${ }^{41}$ a court should have used the market interest rate of a low-risk asset in which $P$ could have invested without particular business acumen. ${ }^{42}$ Some courts chose a rate after presentations by the adversaries at trial, ${ }^{43}$ while others applied interest rates set by statute. ${ }^{44}$ The calculations here will assume that a five percent rate

See generally supra note 3.

${ }^{36}$ For current challenges to the system of lump sum damages, see Comment, Variable Periodic Payments of Damages: An Alternative to Lump Sum Awards, 64 Iowa L. Rev. 138 (1978). The problem of lump sum damages has also received judicial attention. See, e.g., Green v. United States, 530 F. Supp. 633, 644 (E.D. Wis. 1982) ("Ideally, the system would allow an open-ended award requiring the tortfeasors to provide the necessary care for Mrs. Green for the rest of her life. Unfortunately, the law does not permit an award to be made in this fashion."). Other legal systems have procedures for subsequent modification of tort damage judgments. K. ROSENN, LAw AND INELATION 226-29 (1982).

${ }^{37}$ See supra note 25 and accompanying text.

ss See O'Shea v. Riverway Towing Co., 677 F.2d 1194, 1199 (7th Cir. 1982).

3* See Note, supra note 8, at 113-19 (describing this approach as the "traditional approach," id. at 114). See also supra note 14.

to C. GRegory, H. Kalven \& R. Epstein, supra note 1, at 651-55.

11 The selection of the discount rate affects present value calculations markedly. For example, the present value of an annuity of 20 years is nine percent greater if an interest rate of four percent is used rather than an interest rate of five percent. See S. Davidson, C. Stickney \& R. Weil, Financial Accounting: An Introduction to Concepts, MEthods and USES 627 (2d ed. 1979) (comparison of present value factor of an annuity in arrears of 20 years at interest rates of four percent and five percent).

12 See supra note 25 and accompanying text.

${ }^{43} 22$ AM. Jur. 2D Damages $\S 96$, at 142 n.14 (1965).

"Id.; Annot., 105 A.L.R. 234, 235 (1936). 
was used; 45 applied to $\$ 110,960$, that rate yields a net award of $\$ 72,597 .^{.8}$

Had $P$ invested $\$ 72,597$ in a low-risk asset in 1960, withdrawn annually what he would have earned at an average manufacturing job, and reinvested the remainder, the award would have run out in 1973. Consider the steps $P$ would have taken. In 1960, he would have withdrawn $\$ 5548$, the amount he would have earned that year, ${ }^{47}$ and he would have invested the remainder, $\$ 67,049$, in a safe, short-term asset, ${ }^{48}$ such as United States Government Treasury Bills. Given the prevailing rate of interest, $3.41 \%,{ }^{49} P$ 's invested tort award would have grown to $\$ 69,335$ by the beginning of $1961 .{ }^{50}$ At the start of $1961, P$ would have withdrawn what manufacturing workers were earning at the time, $\$ 5703,{ }^{51}$ and invested the remainder at the then-prevailing interest rate, $2.81 \% .{ }^{.2}$ The remaining steps in the calculation are provided in Table 1 , which reveals that by $1973 P$ would have had only $\$ 285$ to compensate him for seven years of lost earnings. ${ }^{53}$ The traditional approach,

15 The choice of a five percent figure is somewhat arbitrary, as a 1960 court could have chosen any rate it liked. However, the choice of a five percent rate is well within the range from which courts around 1960 actually chose discount rates. See, e.g., Matanuska Valley Lines v. Neal, 255 F.2d 632, 636-37 (9th Cir. 1957) (four percent and five percent rates used); Paine v. Commissioner, 236 F.2d 398, 401-02 (8th Cir. 1956) (five percent); Burnett v. Graves, 230 F.2d 49, 54-55 (5th Cir. 1956) (eight percent).

68 The award is calculated as an annuity due; that is, the award is computed so that the annual payment is made at the beginning of the year. The $\$ 72,597$ award is the present value of a 20 -year annuity of $\$ 5548$ due annually at five percent. Discounting a future award can be complicated. Each future year's earnings would have to be discounted by a different rate, reflecting the number of years elapsed since the judgment. These calculations are simplified by the use of an annuity table, which states the rate needed for annuities of different durations and at different rates of interest. See S. DAvidson, C. STICKNEY \& R. WEIL, supra note 41 , at 627 .

47 See supra note 35.

18 Investing in short-term securities allows $P$ to take advantage of swings in the interest rate caused by inflation. Had $P$ invested in a 20 -year security in 1960 , he would have been locked into a low interest rate and would not have benefited from the increases in interest rates in the 1960's. See infra Interest Rate Column, Table 1. Had interest rates fallen, a 20 year investment would have been in his best interests.

6 Financial and Business Statistics, 47 Fed. Reserve Bull. 39, 60 (1961) (Money Market Table).

so $\$ 72,597$ (Initial Award) $-\$ 5548$ (1960 Income) $=\$ 67,049$ (Investment Balance). $\$ 67,049 \times 3.41 \%=\$ 2,380$ (Interest Income). New Balance $=\$ 69,335$. See Table 1 .

B1 NIPA, supra note 13, at 213.

${ }^{82}$ Financial and Business Statistics, 48 Fed. Reserve Buld. 703, 724 (1962) (Money Market Table).

ss The earnings figures used in this analysis are detailed in NIPA, supra note 13, at 212-13 (1960-74 data); NIPA Supp., supra note 13, at 54 (Table 6.9B) (1976-80 data); and National Income and Product Tables, Surv. Current Bus., July 1979, at 15, 55 (Table 6.9) (1975 data). Treasury Bill interest rates are readily available in money market statistics. See 
accordingly, would not have met its goal of compensating $P$ for the earnings he would lose as a result of his accident.

TABLE 1

Traditional Approach

\begin{tabular}{rrrrrr}
\hline \hline Date & $\begin{array}{c}\text { Beginning } \\
\text { Balance }\end{array}$ & $\begin{array}{c}\text { Earnings } \\
\text { Withdrawn }\end{array}$ & $\begin{array}{c}\text { Investment } \\
\text { Balance }\end{array}$ & $\begin{array}{c}\text { Interest } \\
\text { Rate }\end{array}$ & $\begin{array}{r}\text { Ending } \\
\text { Balance }\end{array}$ \\
\hline 1960 & $\$ 72,597$ & $\$ 5,548$ & $\$ 67,049$ & $3.41 \%$ & $\$ 69,335$ \\
1961 & 69,335 & 5,703 & 63,632 & 2.81 & 65,420 \\
1962 & 65,420 & 5,919 & 59,501 & 3.01 & 61,292 \\
1963 & 61,292 & 6,115 & 55,177 & 3.30 & 56,998 \\
1964 & 56,998 & 6,419 & 50,579 & 3.74 & 52,471 \\
1965 & 52,471 & 6,566 & 45,905 & 4.06 & 47,769 \\
1966 & 47,769 & 6,804 & 40,965 & 5.07 & 43,042 \\
1967 & 43,042 & 7,048 & 35,994 & 4.71 & 37,689 \\
1968 & 37,689 & 7,537 & 30,152 & 5.46 & 31,798 \\
1969 & 31,798 & 7,973 & 23,825 & 6.79 & 25,443 \\
& & & & & \\
1970 & 25,443 & 8,381 & 17,062 & 6.49 & 18,169 \\
1971 & 18,169 & 8,882 & 9,287 & 4.67 & 9,721 \\
1972 & 9,721 & 9,449 & 272 & 4.77 & 285 \\
1973 & 285 & 10,027 & $(9,742)$ & 7.01 & \\
1974 & & 10,834 & & 7.71 & \\
1975 & & 11,903 & & 6.30 & \\
1976 & & 12,836 & & 5.52 & \\
1977 & & 13,866 & & 5.71 & \\
1978 & & 14,949 & & 7.74 & \\
1979 & & 16,259 & & 9.75 & \\
\hline
\end{tabular}

DERIVED FROM SOURCES CITED supra note 53.

Financial and Business Statistics, FED. Reserve BuLL., July 1980, at A1, A27; Financial and Business Statistics, Fed. Reserve Bull., March 1977, at A1, A27; Financial and Business Statistics, FEd. Reserve BulL., Feb. 1974, at A1, A33-34; Financial and Business Statistics, Fed. Reserve Bull., Jan. 1973, at A1, A35; Financial and Business Statistics, Fed. Reserve Bull., Jan. 1968, at A1, A29; Financial and Business Statistics, 51 Fed. Reserve BuLl. 117, 142 (1965); Financial and Business Statistics, 48 Fed. Reserve Bull., 703, 724 (1962).

For $P$ to have made up the seven-year income shortfall, he would have had to invest in more speculative assets with higher rates of return but also higher risks of failure. A tort victim should not be forced to take such risks. See supra note 25 and accompanying text. 


\section{B. Inflate-Discount Method}

Courts increasingly have rejected the traditional approach in favor of the inflate-discount method, which attempts to account for future inflation. ${ }^{54}$ The award is determined by multiplying current earnings by an expected inflation rate and then discounting the product in the traditional fashion. ${ }^{55} \mathrm{Had}$ a hypothetical 1960 court used the inflate-discount method to calculate $P$ 's award, $P$ would have fared better than under the traditional approach; the award, however, still would have fallen short of compensating $P$ for twenty years' lost earnings.

Because inflation was not a matter of great concern for courts or economists in $1960,{ }^{56}$ the inflate-discount method was not used then. ${ }^{87}$ Determining the inflation rate that a 1960 court would have used in the equation, therefore, is speculative. ${ }^{.8}$ It is nonetheless reasonable to use a three percent rate, because this rate is consistent with the economy of the early 1960's. ${ }^{50}$ Inflating P's 1960

s4 See Doca v. Marina Mercante Nicaraguense, S.A., 634 F.2d 30, 36-40 (2d Cir. 1980), cert. denied, 451 U.S. 971 (1981).

ss The Ninth Circuit explained the inflate-discount method as follows: "The lower court must first estimate future income and expenses, taking into account estimated changes in the purchasing power of the dollar, and then discount this future net income stream to its present value." United States v. English, 521 F.2d 63, 75 (9th Cir. 1975). Stated algebraically, the court estimates $\sum_{t=1}^{n} \frac{(1+i)^{t}}{(1+r)^{t}}$, where $i$ is the inflation rate, $r$ is the interest rate, $t$ is time, and $n$ is the number of years until retirement.

sB Economic models constructed in the mid-1950's to predict the economic future of the nation explicitly assumed inflation to be zero. See supra note 14 .

${ }^{67}$ The Doca court outlined the trend toward considering inflation when computing damages. The cases it cited show that a recognition of the importance of inflation began in the mid-1970's. Doca v. Marina Mercante Nicaraguense, S.A., 634 F.2d 30, 35-36 (2d Cir. 1980), cert. denied, 451 U.S. 971 (1981).

${ }^{88}$ Like any other prediction, selecting a future inflation factor for an award to be made today is also speculative. Although the inflation rate to be used in the calculation is a factual issue subject to adversarial proceedings, some courts have restricted the admissibility of economic evidence of the inflation rate. E.g., Bach v. Penn Cent. Transp. Co., 502 F.2d 1117, 1122 (6th Cir. 1974). The Sixth Circuit saw nothing inconsistent in refusing to allow expert testimony, which might have made the jury's task less irrational, reasoning that inflation is a phenomenon "within the common experience of all jurors." Id. at 1122. It further explained its reasoning in Morvant v. Construction Aggregates Corp., 570 F.2d 626, 631-33 (6th Cir.), cert. dismissed, 439 U.S. 801 (1978), noting that the Bach court rejected expert testimony because of the fear of excessive awards. "What Bach aimed at preventing was a projection of statistical data so attenuated as to be a reductio ad absurdum, thus allowing damages to be ballooned beyond all rational experience." Id. at 632 n.5.

so Inflation averaged about two percent annually during the 1950's. Bureau of Labor Statistics, Current Labor Statistics, MonTHLy LaB. Rev., Nov. 1970, at 76, 93. Using a three percent rate resolves all doubt in the plaintiff's favor. A three.percent inflation rate also is supported by the interest rates paid in 1960 by low-risk assets such as one-year Treasury Bills $(3.41 \%)$, corporate bonds $(4.41 \%$ (Aaa) and $5.19 \%$ (Baa)), and preferred stock 
TABLE 2

INFLATE-DisCOUNT METHOD

\begin{tabular}{cccccr}
\hline \hline Date & $\begin{array}{c}\text { Beginning } \\
\text { Balance }\end{array}$ & $\begin{array}{c}\text { Earnings } \\
\text { Withdrawn }\end{array}$ & $\begin{array}{c}\text { Investment } \\
\text { Balance }\end{array}$ & $\begin{array}{c}\text { Interest } \\
\text { Rate }\end{array}$ & $\begin{array}{c}\text { Ending } \\
\text { Balance }\end{array}$ \\
\hline 1960 & $\$ 93,004$ & $\$ 5,548$ & $\$ 87,456$ & $3.41 \%$ & $\$ 90,438$ \\
1961 & 90,438 & 5,703 & 84,735 & 2.81 & 87,116 \\
1962 & 87,116 & 5,919 & 81,197 & 3.01 & 83,641 \\
1963 & 83,641 & 6,115 & 77,526 & 3.30 & 80,084 \\
1964 & 80,084 & 6,419 & 73,665 & 3.74 & 76,420 \\
1965 & 76,420 & 6,566 & 69,854 & 4.06 & 72,690 \\
1966 & 72,690 & 6,804 & 65,886 & 5.07 & 69,226 \\
1967 & 69,226 & 7,048 & 62,178 & 4.71 & 65,107 \\
1968 & 65,107 & 7,537 & 57,570 & 5.46 & 60,713 \\
1969 & 60,713 & 7,973 & 52,740 & 6.79 & 56,321 \\
1970 & 56,321 & 8,381 & 47,940 & 6.49 & 51,051 \\
1971 & 51,051 & 8,882 & 42,169 & 4.67 & 44,138 \\
1972 & 44,138 & 9,449 & 34,689 & 4.77 & 36,344 \\
1973 & 36,344 & 10,027 & 26,317 & 7.01 & 28,162 \\
1974 & 28,162 & 10,834 & 17,328 & 7.71 & 18,664 \\
1975 & 18,644 & 11,903 & 6,761 & 6.30 & 7,187 \\
1976 & 7,187 & 12,836 & $(5,649)$ & 5.52 & \\
1977 & & 13,866 & & 5.71 & \\
1978 & & 14,949 & & 7.74 & \\
1979 & & 16,259 & & 9.75 & \\
\hline
\end{tabular}

DERIVED RROM SOURCES CITED supra note 53.

wages annually by three percent and then discounting each year's earnings by five percent yields an adjusted figure of $\$ 93,004 .^{60} \mathrm{Ta}-$ ble 2 shows that the larger award under the inflate-discount method would have lasted longer than the traditional approach's award, but it, too, would have been undercompensatory, running out four years short of the goal of 1980 .

(4.75\%). See Financial and Business Statistics, 48 FrD. REserve Bull. 703, 724 (1962); Financial and Business Statistics, 47 Frd. Reserve Butl. 39, 60 (1961). These interest rates reflect an inflation component and a real interest rate component. See supra notes 2429 and accompanying text. Because the real interest rate is assumed here to be two percent, see supra notes $28-29$ and accompanying text; infra note 63 and accompanying text, the nominal interest rates listed above reflect on average an inflation rate of about $2.5 \%$. See supra notes 23-31 and accompanying text. Again resolving doubt in the plaintiff's favor, three percent is a reasonable estimate. Finally, using a three percent rate is consistent with using a five percent interest rate in discounting, see supra note $\mathbf{4 5}$ and accompanying text; when the real interest rate of two percent is subtracted, a three percent inflation rate is left.

co Starting with the average manufacturing worker's 1960 earnings, NIPA, supra note 13, at 212-13, an inflate-discount court would compute $P$ 's award as follows: 


\section{Partial Offset Method}

Some courts, led by the Second Circuit, have used another method, partial offset, to account for the persistent problem of inflation. ${ }^{61}$ A Second Circuit panel explained the mechanics and rationale of the method in 1980 in Doca v. Marina Mercante Nicaraguense, S.A. ${ }^{32}$ The court noted that regardless of the level of inflation, the interest rate traditionally used to discount awards is two percentage points greater than the inflation rate. ${ }^{63}$ The court recommended ${ }^{64}$ therefore, that trial courts discount tort awards by

\begin{tabular}{lccc}
\hline \hline & $\begin{array}{c}\text { Annual Earnings } \\
\text { Inflated at 3\% }\end{array}$ & $\begin{array}{c}\text { Discount Factor } \\
\text { at 5\% }\end{array}$ & $\begin{array}{c}\text { Discounted } \\
\text { Sum }\end{array}$ \\
\hline 1960 & $\$ 5548$ & 1.00000 & $\$ 5548$ \\
1961 & 5714 & .95238 & 5442 \\
1962 & 5886 & .90703 & 5339 \\
1963 & 6062 & .86384 & 5237 \\
1964 & 6244 & .82270 & 5137 \\
1965 & 6432 & .78353 & 5040 \\
1966 & 6625 & .74622 & 4944 \\
1967 & 6823 & .71068 & 4849 \\
1968 & 7028 & .67684 & 4757 \\
1969 & 7239 & .64461 & 4666 \\
1970 & 7456 & .61391 & 4577 \\
1971 & 7680 & .58468 & 4490 \\
1972 & 7910 & .55684 & 4405 \\
1973 & 8147 & .53032 & 4321 \\
1974 & 8392 & .50507 & 4239 \\
1975 & 8644 & .48102 & 4158 \\
1976 & 8903 & .45811 & 4079 \\
1977 & 9170 & .43630 & 4001 \\
1978 & 9445 & .41552 & 3925 \\
1979 & 9728 & .39573 & 3850 \\
. & & & $\$ 93,004$ \\
\hline
\end{tabular}

Discount factors found in S. DAvidson, C. STICKNEY \& R. WeIl, supra note 41, at 625. Decimals retained in calculations; entries rounded to nearest whole number.

-1 Doca v. Marina Mercante Nicaraguense, S.A., 634 F.2d 30, 36-37 (2d Cir. 1980), cert. denied, 451 U.S. 971 (1981).

o2 Id. See also Feldman v. Allegheny Airlines, Inc., 382 F. Supp. 1271 (D. Conn. 1974), aff'd, 524 F.2d 384 (2d Cir. 1975) (use of partial offset method with $1.5 \%$ discount rate affirmed). Because the Feldman court calculated "just damages" as required by a Connecticut statute, it is doubtful that Feldman is a binding precedent for other Second Circuit decisions. 524 F.2d at 393 (Friendly, J., concurring dubitante).

63 Doca, 634 F.2d at 39 \& n.10. This figure in essence is the real interest rate. See supra notes 28-29 and accompanying text. This comment assumes that the mean real interest rate is two percent.

of Recognizing that "predictive techniques are constantly being refined," the court refused to adopt the partial offset method as a rule of law. Doca, 634 F.2d at 39 . In fact, the court stated that litigants in the Second Circuit are free to account for inflation in other ways, but if the parties do not agree about the method or if they do not present evidence concerning inflation and discount rates, district courts are authorized to use the two percent 
the underlying interest rate of two percent ${ }^{85}$ rather than employ

TABLE 3

Partial Offset Method

\begin{tabular}{cccccc}
\hline \hline Date & $\begin{array}{c}\text { Beginning } \\
\text { Balance }\end{array}$ & $\begin{array}{c}\text { Earnings } \\
\text { Withdrawn }\end{array}$ & $\begin{array}{c}\text { Investment } \\
\text { Balance }\end{array}$ & $\begin{array}{c}\text { Interest } \\
\text { Rate }\end{array}$ & $\begin{array}{c}\text { Ending } \\
\text { Balance }\end{array}$ \\
\hline 1960 & $\$ 92,532$ & $\$ 5,548$ & $\$ 86,984$ & $3.41 \%$ & $\$ 89,950$ \\
1961 & 89,950 & 5,703 & 84,247 & 2.81 & 86,614 \\
1962 & 86,614 & 5,919 & 80,695 & 3.01 & 83,124 \\
1963 & 83,124 & 6,115 & 77,009 & 3.30 & 79,550 \\
1964 & 79,550 & 6,419 & 73,131 & 3.74 & 75,866 \\
1965 & 75,866 & 6,566 & 69,300 & 4.06 & 72,114 \\
1966 & 72,114 & 6,804 & 65,310 & 5.07 & 68,621 \\
1967 & 68,621 & 7,048 & 61,573 & 4.71 & 64,473 \\
1968 & 64,473 & 7,537 & 56,936 & 5.46 & 60,045 \\
1969 & 60,045 & 7,973 & 52,072 & 6.79 & 55,608 \\
1970 & 55,608 & 8,381 & 47,227 & 6.49 & 50,292 \\
1971 & 50,292 & 8,882 & 41,410 & 4.67 & 43,344 \\
1972 & 43,344 & 9,449 & 33,895 & 4.77 & 35,512 \\
1973 & 35,512 & 10,027 & 25,485 & 7.01 & 27,272 \\
1974 & 27,272 & 10,834 & 16,438 & 7.71 & 17,705 \\
1975 & 17,705 & 11,903 & 5,802 & 6.30 & 6,168 \\
1976 & 6,168 & 12,836 & $(6,668)$ & 5.52 & \\
1977 & & 13,866 & & 5.71 & \\
1978 & & 14,949 & & 7.74 & \\
1979 & & 16,259 & & 9.75 & \\
\hline
\end{tabular}

DERIVED RROM SOURCES CITED supra note 53.

the two-step inflate-discount method. ${ }^{68}$

partial offset rate. Id. at 40.

ss The court defended using the two percent discount rate, although it acknowledged that interest rates sometimes are less than two points higher than the inflation rate. The court noted that " $[w]$ hen prices are rising, the rate of interest tends to be high but not as high as it should be to compensate for the rise." "Id. at $39-40$ \& n.11 (quoting I. Fisurr, supra note 27, at 43). This gap is known as the "Fisher effect" because it was first observed by Irving Fisher. See Note, supra note 8 , at 128-29. The Doca court argued that in such circumstances wage increases would be smaller than the inflation rate; therefore discounting, rather than inflating, would still be the most accurate way to predict lost future wages. Doca, 634 F.2d at 39-40 \& nn.11-12.

so The results of the partial offset and inflate-discount methods should be "very nearly identical.' " Doca, 634 F.2d at 34 (quoting Feldman v. Allegheny Airlines, Inc., 524 F.2d 384, 
A court in 1960 would have encountered little difficulty applying the partial offset method because it requires neither predictions of future inflation nor determinations of future discount rates. As Table 3 reveals, however, the partial offset award also would have been undercompensatory. Using Doca's choice of a two percent inflation-adjusted discount rate, $P$ 's gross predicted earnings of $\$ 110,960$ would have been discounted to yield an award of $\$ 92,532,{ }^{67}$ and $P$ would have exhausted his funds in 1976, four years ahead of schedule.

\section{Total Offset Method}

The total offset method ${ }^{88}$ is the most radical departure from the traditional approach because it does not discount the Step I prediction. Unlike the partial offset method, which assumes that the interest rate used to discount awards exceeds the inflation rate by two percentage points, the total offset method assumes that inflation equals and therefore completely offsets the discount rate. Because inflating and then discounting by the same amount would result in the undiscounted figure, the total offset method awards the full Step I sum. ${ }^{80}$

391 (2d Cir. 1975) (Friendly, J., concurring dubitante)). The inflate-discount method calculates $\sum_{t=1}^{n} \frac{(1+i)^{t}}{(1+r)^{t}}$, while the partial offset method calculates $\sum_{t=1}^{n} \frac{1}{(1+(r-i))^{t}}$, where $i$ is

the rate of interest, $r$ is the discount rate, $t$ is elapsed time, and $n$ is the number of years until expected retirement. The expressions are nearly identical in most calculations. Compare Table 2 with Table 3.

${ }^{67}$ For discount factor tables, see S. Davidson, C. STICKNEY \& R. WEIL, supra note 41 , at 624-27.

68 The total offset method was first applied in state courts. See Beaulieu v. Elliott, 434 P.2d 665 (Alaska 1967); Kaczkowski v. Bolubasz, $491 \mathrm{~Pa} .561,421$ A.2d 1027 (1980). The Eighth Circuit has held that Chesapeake \& O. Ry. v. Kelly, 241 U.S. 485 (1916), see supra note 5 , precludes use of the total offset method in federal claims, Taenzler v. Burlington N., 608 F.2d 796, 802 (8th Cir. 1979), but the Third Circuit recently applied the total offset approach to a claim brought under the federal Longshoremen's and Harbor Worker's Compensation Act in Pfeifer v. Jones \& Laughlin Steel Corp., 678 F.2d 453 (3d Cir. 1982).

60 The opinion in Beaulieu, the first case to adopt the total offset method, was based on a common-sense understanding of the economy, rather than on careful economic exposition, see 434 P.2d at 671, and it was criticized as reflecting the "exceptional conditions of inflation in a 'frontier' state," Feldman v. Allegheny Airlines, Inc., 382 F. Supp. 1271, 1292 n.26 (D. Conn. 1974), aff'd, 524 F.2d 384 (2d Cir. 1975). The Pennsylvania Supreme Court's adoption of the total offset method in Kaczkowski v. Bolubasz, $491 \mathrm{~Pa} .561,421 \mathrm{~A} .2 \mathrm{~d} 1027$ (1980), similarly lacked reasoned economic discussion. The court noted the persistence of inflation in our economy, id. at 572-73, $421 \mathrm{~A} .2 \mathrm{~d}$ at 1033, and the close relationship between interest rates and inflation, id. at 581, $421 \mathrm{~A} .2 \mathrm{~d}$ at 1038 . From these observations, it summarily concluded that the use of the total offset method "provides at least as much, if not greater, accuracy" as the partial offset method, whose discount factor recognizes changes in 
TABLE 4

Total Offset MethoD-Beaulieu

\begin{tabular}{rrrrrr}
\hline \hline Date & $\begin{array}{c}\text { Beginning } \\
\text { Balance }\end{array}$ & $\begin{array}{c}\text { Earnings } \\
\text { Withdrawn }\end{array}$ & $\begin{array}{r}\text { Investment } \\
\text { Balance }\end{array}$ & $\begin{array}{c}\text { Interest } \\
\text { Rate }\end{array}$ & $\begin{array}{r}\text { Ending } \\
\text { Balance }\end{array}$ \\
\hline 1960 & $\$ 110,960$ & $\$ 5,548$ & $\$ 105,412$ & $3.41 \%$ & $\$ 109,007$ \\
1961 & 109,007 & 5,703 & 103,304 & 2.81 & 106,207 \\
1962 & 106,207 & 5,919 & 100,288 & 3.01 & 103,307 \\
1963 & 103,307 & 6,115 & 97,192 & 3.30 & 100,399 \\
1964 & 100,399 & 6,419 & 93,980 & 3.74 & 97,495 \\
1965 & 97,495 & 6,566 & 90,929 & 4.06 & 94,621 \\
1966 & 94,621 & 6,804 & 87,817 & 5.07 & 92,269 \\
1967 & 92,269 & 7,048 & 85,221 & 4.71 & 89,235 \\
1968 & 89,235 & 7,537 & 81,698 & 5.46 & 86,159 \\
1969 & 86,159 & 7,973 & 78,186 & 6.79 & 83,495 \\
1970 & 83,495 & 8,381 & 75,114 & 6.49 & 79,989 \\
1971 & 79,989 & 8,882 & 71,107 & 4.67 & 74,428 \\
1972 & 74,428 & 9,449 & 64,979 & 4.77 & 68,079 \\
1973 & 68,079 & 10,027 & 58,052 & 7.01 & 62,121 \\
1974 & 62,121 & 10,834 & 51,287 & 7.71 & 55,241 \\
1975 & 55,241 & 11,903 & 43,338 & 6.30 & 46,068 \\
1976 & 46,068 & 12,836 & 33,232 & 5.52 & 35,066 \\
1977 & 35,066 & 13,866 & 21,200 & 5.71 & 22,411 \\
1978 & 22,411 & 14,949 & 7,462 & 7.74 & 8,040 \\
1979 & 8,040 & 16,259 & $(8,219)$ & 9.75 & \\
\hline
\end{tabular}

DERIVED FROM SOURCES CITED supra note 53.

The first court to advance the total offset rule was the Alaska Supreme Court in Beaulieu v. Elliott, ${ }^{70}$ in 1967. Had a hypotheti-

inflation and the rate of interest. Id. at 580-81, 421 A.2d at 1037-38.

The Kaczkowski court also criticized Feldman, the major partial offset precedent at the time of its decision. Although the Kaczkowski court read Feldman to require trial courts to predict future interest rates, which is "as difficult as predicting future inflation," Kaczkowski, $491 \mathrm{~Pa}$. at 582, $421 \mathrm{A.2d}$ at 1038, Feldman holds that courts need only observe the constant relation between inflation and interest rates, and then discount by an inflationadjusted discount rate. Feldman, 382 F. Supp. at 1293-95. The selection of a discount rate by the Feldman and Doca courts was based on historical observations, not on predictions of the future. Doca, 634 F.2d at 38-39 (discussing Feldman).

70 434 P.2d 665 (Alaska 1967). The court's rationale challenged the assumption underlying discounting: rather than assuming that victims will invest their awards and receive stable returns, the court asserted that some victims will invest unwisely and lose everything. Id. at 671. In State v. Guinn, 555 P.2d 530 (Alaska 1976), the court explained that its adop- 
cal 1960 court used Beaulieu's method to calculate $P$ 's award, $P$ would have received the undiscounted sum of $\$ 110,960 .{ }^{71}$ As Table 4 indicates, this award would have compensated $P$ fully; $P$ would not have exhausted the award until mid-1979, virtually the exact date $P$ would have retired had he not been injured. ${ }^{72}$

In Kaczkowski v. Bolubasz, ${ }^{73}$ the Pennsylvania Supreme Court applied the total offset method, but it calculated the Step I prediction differently from the Alaska courts. ${ }^{74}$ The Pennsylvania Supreme Court increased its Step I prediction by the amount it expected wages to increase annually due to increasing labor productivity. ${ }^{75} \mathrm{Had}$ a court used the Kaczkowski variant of the total offset method in 1960, it probably would have predicted labor productivity to grow at a rate of $2.5 \%$ annually ${ }^{76}$ Applying this figure to $P$ 's 1960 earnings of $\$ 5548$ yields a productivity-adjusted, undiscounted sum over twenty years of $\$ 141,722 .{ }^{77}$ Because that amount is much greater than the Step I prediction used elsewhere and is not discounted under the Kaczkowski method, it is not surprising that this award would have been overcompensatory. Table 5 demonstrates that it would have compensated $P$ for his lost earnings and conferred on him a windfall of nearly $\$ 80,000$.

tion of the Beaulieu rule was no longer based on the theory of risky investment; rather, the underlying theory was that "the rate of depreciation in the value of the dollar, attributable to ongoing inflation, approximately offsets the financial windfall otherwise attributable to a failure to discount to present value." Id. at 545. The Guinn decision also allowed courts to account for foreseeable future wage increases. It did not authorize courts to conduct wholesale investigations into the plaintiff's future wage increases but did allow trial courts to account for future "step-wage" increases, such as those keyed to union seniority programs. It thus recognized that wages normally vary with age. Id. at 546. See supra note 3. See also Alaska Airlines v. Sweat, 568 P.2d 916, 937 (Alaska 1977) (limiting Beaulieu to inflationary, but not merit, wage increases).

${ }^{71}$ See supra note 35 and accompanying text.

72 The plaintiff did run out of money in the final months of the plan. Nonetheless, the system is not undercompensatory. The interest rate used in this analysis was a very conservative measure. Had the plaintiff invested in other safe, low-risk investments, or had the model allowed for continuous compounding of interest, his return would have been sufficient to make up the final months' shortfall.

${ }^{73} 491 \mathrm{~Pa} .561,421$ A.2d 1027 (1980).

7 Id. at $580,421 \mathrm{~A} .2 \mathrm{~d}$ at 1037 .

${ }^{75}$ Id. at 579-80, 421 A.2d at 1036-37. See generally supra notes 17-22 and accompanying text (discussing labor productivity).

${ }^{78}$ Four separate economic models presented in 1954 chose $2.5 \%$ as a reliable estimate of future changes in productivity. Potential Economic Growth, supra note 14, at 21-23. Experience has confirmed the accuracy of the 1954 predictions. The average rate of productivity growth measured over three decades has been $2.6 \%$. Economic REPoRT, supra note 19 , at 279 (Table B-41).

77 Inflating the average manufacturing worker's 1960 earnings, NIPA, supra note 13 , at $212-13$, at $2.5 \%$ annually produces the following income sums: 


\section{TABLE 5}

Total Offset Method-Kaczkowski

\begin{tabular}{rrrrrr}
\hline \hline Date & $\begin{array}{c}\text { Beginning } \\
\text { Balance }\end{array}$ & $\begin{array}{c}\text { Earnings } \\
\text { Withdrawn }\end{array}$ & $\begin{array}{c}\text { Investment } \\
\text { Balance }\end{array}$ & $\begin{array}{c}\text { Interest } \\
\text { Rate }\end{array}$ & $\begin{array}{c}\text { Ending } \\
\text { Balance }\end{array}$ \\
\hline 1960 & $\$ 141,722$ & $\$ 5,548$ & $\$ 136,174$ & $3.41 \%$ & $\$ 140,818$ \\
1961 & 140,818 & 5,703 & 135,115 & 2.81 & 138,912 \\
1962 & 138,912 & 5,919 & 132,993 & 3.01 & 136,996 \\
1963 & 136,996 & 6,115 & 130,881 & 3.30 & 135,200 \\
1964 & 135,200 & 6,419 & 128,781 & 3.74 & 133,597 \\
& & & & & \\
1965 & 133,597 & 6,566 & 127,031 & 4.06 & 132,188 \\
1966 & 132,188 & 6,804 & 125,384 & 5.07 & 131,741 \\
1967 & 131,741 & 7,048 & 124,693 & 4.71 & 130,566 \\
1968 & 130,566 & 7,537 & 123,029 & 5.46 & 129,746 \\
1969 & 129,746 & 7,973 & 121,773 & 6.79 & 130,041 \\
& & & & & \\
1970 & 130,041 & 8,381 & 121,660 & 6.49 & 129,556 \\
1971 & 129,556 & 8,882 & 120,674 & 4.67 & 126,309 \\
1972 & 126,309 & 9,449 & 116,860 & 4.77 & 122,434 \\
1973 & 122,434 & 10,027 & 112,407 & 7.01 & 120,287 \\
1974 & 120,287 & 10,834 & 109,453 & 7.71 & 117,892 \\
1975 & 117,892 & 11,903 & 105,989 & 6.30 & 112,666 \\
1976 & 112,666 & 12,836 & 99,830 & 5.52 & 105,341 \\
1977 & 105,341 & 13,866 & 91,475 & 5.71 & 96,698 \\
1978 & 96,698 & 14,949 & 81,749 & 7.74 & 88,076 \\
1979 & 88,076 & 16,259 & 71,817 & 9.75 & 78,819 \\
\hline
\end{tabular}

DRRIVED FROM SOURCES CITED supra note 53.

\begin{tabular}{lrrrrrr}
\hline \hline Year & Income & Year & Income & Year & Income \\
\hline 1960 & $\$ 5548$ & 1967 & $\$ 6595$ & 1974 & $\$ 7839$ \\
1961 & 5687 & 1968 & 6760 & 1975 & 8035 \\
1962 & 5829 & 1969 & 6929 & 1976 & 8236 \\
1963 & 5975 & 1970 & 7102 & 1977 & 8442 \\
1964 & 6124 & 1971 & 7279 & 1978 & 8653 \\
1965 & 6277 & 1972 & 7461 & $\underline{1979}$ & $\$ 869$ \\
1966 & 6434 & 1973 & 7648 & Sum Total & $\$ 141,722$ \\
\hline
\end{tabular}

Decimals retained in calculations; entries rounded to nearest whole number.

Under the total offset method, the sum total would not be discounted. 


\section{The Economics of the Total Offset Method}

Although courts have been hesitant to undertake systematic analyses of the economics underlying the accuracy of lost future earnings awards, the relationships among the phenomena affecting the awards are fairly simple. The inflating factors are wage increases due to inflation and productivity gains $;^{78}$ the discounting factor is the interest rate, which reflects both inflation and the real interest rate. ${ }^{79}$ Because one should use the same inflation rate both to inflate and to discount an award, ${ }^{80}$ the net effect of inflation is zero; inflation therefore can be ignored. Without inflation, the only factors to account for are productivity-based wage increases and the discount effect of the real interest rate.

That the only relevant factors are productivity and the real interest rate helps explain the deficiencies in the hypothetical awards described above. The traditional method is undercompensatory because it fails to increase the award to account for productivity gains, and because it discounts the award not only by the real interest rate, but by the inflation rate. ${ }^{81}$ The inflate-discount method is more nearly accurate because the net effect is to discount only by the real interest rate; ${ }^{82}$ its failing is that it does not increase the award for productivity gains. The partial offset method is similarly undercompensatory because it also does not inflate the award to account for wage increases caused by productivity gains. ${ }^{83}$ The Kaczkowski variant of the total offset method suffers from the opposite problem: because it increases the Step I prediction by expected productivity gains and then fails to discount by the real interest rate, it is overcompensatory. ${ }^{84}$

The relation between the real interest rate and productivity increases also explains the accuracy of the total offset method. An accurate award should result from multiplying the Step I prediction by an annual productivity gain factor and then discounting by the real interest rate. If both factors are equivalent, however, doing

78 See supra notes $12-22$ and accompanying text.

79 See supra notes 23-31 and accompanying text.

so O'Shea v. Riverway Towing Co., 677 F.2d 1194, 1200 (7th Cir. 1982).

81 See supra notes 39-53 and accompanying text. The traditional method uses the nominal interest rate, which includes inflation and real interest rates.

s2 See supra notes 54-60 and accompanying text. Some inflate-discount courts have in net effect inflated awards. See, e.g., Sampson v. Missouri P.R.R., 560 S.W.2d 573 (Mo. 1978) (estimating the sum of inflation and future changes in productivity to be $2.3 \%$ higher than the discount rate). These awards are overcompensatory.

ss See supra notes 61-67 and accompanying text.

s4 See supra notes 73-77 and accompanying text. 
so is tantamount to using the total offset method-one increases and decreases the award by the same amount, leaving no net Step II adjustment. ${ }^{85}$ In fact, the average productivity rate increased by $2.57 \%$ from 1950 through $1979,{ }^{86}$ well within the range of real interest rate estimates advanced by economists. ${ }^{87}$ The apparent congruence of productivity gains and real interest rates during that period explains why the total offset method, as illustrated in Table 4, predicted $P$ 's lost future earnings most accurately. ${ }^{88}$,

There is reason to expect the rate at which productivity increases to continue roughly to equal the real interest rate. ${ }^{89}$ If that
ss The total offset system is represented algebraically as:
$\sum_{t=1}^{n} \frac{(1+i+\Delta P)^{i}}{(1+i)^{i}}$,

where $\mathrm{i}$ is inflation, $\Delta \mathrm{P}$ is the change in productivity, $\mathrm{r}$ is the nominal interest rate, $t$ is time, and $n$ is the number of years until retirement. The nominal interest rate, however, is composed of inflation and a real interest rate $\left(r^{*}\right): r=\left(i+r^{*}\right)$. The total offset system assumes that factors increasing tort awards balance factors decreasing tort awards. If $r^{*}=\Delta P$, then $(1+i+\Delta P)=\left(1+i+r^{*}\right)$, and the inflation factor washes out, leaving $\frac{(1+\Delta P)^{\ell}}{\left(1+r^{*}\right)^{t}}=1$. Hence, the offset is total.

s6 Economic Rrport, supra note 19, at 279 (Table B-41).

77 Recent government projections assert that the rate of annual growth in the productivity of labor will range from $1.4 \%$ to $2.6 \%$. Kutscher, supra note 22 , at 10 . Though speculative, as are all estimates, this projection is no more uncertain than any courtroom estimate. The mean of this range of projected productivity change, two percent, is precisely the real interest rate used in this comment and by the Doca court. See supra note 29; supra note 63 and accompanying text.

3ee supra notes 68-72 and accompanying text.

"The real interest rate and the rate of change in productivity approach an equilibrium condition in which the two rates are equal. Entrepreneurs will borrow to invest in productive enterprises until the return from their investment is equal to the cost of the borrowed funds. Accordingly, if the real interest rate is less than the economy's productivity, increased investment will take place, driving up the demand for money and increasing the interest rate until it equals the productivity of investment. Likewise, if the real interest rate is greater than the productive return from investment, investment will slow until the two rates become equal. This phenomenon was noted by Irving Fisher, who claimed that the interest rate and the return on productive investments would be equal. I. FisHRR, supra note 27, at 182-83. There is, therefore, a theoretical as well as an empirical relation between the real interest rate and the rate of change in labor productivity.

Although in equilibrium the real interest rate should equal the rate of return from productive investments, in recent periods the two have not been equal. The real rate of interest, as derived from comparing current interest and inflation rates, has been far greater than the change in productivity. In June 1982, estimates of inflation ranged from six to seven percent, Wall St. J., June 23, 1982, at 3, col. 1, while six-month U.S. Treasury Bills sold at yields over $14 \%$, id. at 39 , col. 3 . This suggests a real interest rate of seven percent, far greater than the recession-slowed productivity change of one percent projected for 1981, Bureau of Labor Statistics, Current Labor Statistics, Monthly LaB. Rev., Mar. 1982, at 57, 92 (Table 32) (output per hour of all persons) (preliminary estimate).

There are several reasons for this disequilibrium. First, the observed real interest rate probably is not accurate, for the current nominal interest rate incorporates expected as well as current inflation. Because expected inflation may well be higher than current rates, the 
relationship continues, the total offset method will continue to be the most accurate way to calculate compensation for lost future earnings. Because one cannot be certain that inflation, productivity, and interest rates will continue indefinitely to offset each other completely, however, the analysis presented here does not dictate that courts adopt the total offset method as a rule of law. ${ }^{90}$ Rather, it supports creating a rebuttable presumption that the total offset method best accommodates the influences of inflation, productivity gains, and the time value of money on lost future earnings. Such a rule would make it reversible error for a court to use another method unless there is evidence in the record to support the substitute method. Use of the total offset method in this manner would allow courts the flexibility. necessary to calculate damages while assuring that the calculations are "analytical rather than ... intuitive undertaking[s]."

\section{ConClusion}

The goal of a court awarding damages for lost future earnings is to provide the victim with a sum of money that will, in fact, replace the money he would have earned had there been no disabling accident. Awards that do not account for wage increases due to inflation and labor productivity gains are likely to be undercompensatory. Conversely, awards that are not discounted to account for the time value of money will be overcompensatory. The empirical analysis in this comment shows that the total offset method would have produced awards in 1960 far more accurate than

real interest rate is more likely to be in the range suggested supra note 29 . Second, the productivity of labor is influenced by the makeup of the labor force. For example, fluctuating birthrates and participation rates can swell the ranks of the employed and affect output per work hour, the observed productivity measure. Third, consistent with Arthur Okun's theory, productivity also responds to business cycles, decreasing during a recession such as existed in June 1982. See Okun, supra note 20 . Finally, interest rates are influenced by monetary policy, which may have altered current interest rates greatly.

${ }^{\circ 0}$ Compare O'Shea v. Riverway Towing Co., 677 F.2d 1194, 1201 (7th Cir. 1982) (refusing to adopt a particular method as a rule of law) with Kaczkowski v. Bolubasz, $491 \mathrm{~Pa} .561$, 583, 421 A.2d 1027, 1038-39 (1980) (adopting total offset method as rule of law).

22 O'Shea, 677 F.2d at 1201 . Some courts have excluded economic evidence in an effort to keep damage calculations simple. Sixth Circuit cases provide notable examples. See supra note 58. See also Note, supra note 8, at 119-21. Other courts have expressed a similar concern: "The average accident trial should not be converted into a graduate seminar on economic forecasting." Doca v. Marina Mercante Nicaraguense, S.A., 634 F.2d 30, 39 (2d Cir. 1980), cert. denied, 451 U.S. 971 (1981). For an example of the difficulty of admitting proper inflation evidence, see Alma v. Manufacturers Hanover Trust Co., 684 F.2d 622 (9th Cir. 1982). The total offset method is advantageous in that it produces an analytically sound award without complex calculations or forecasting. 
awards calculated according to methods courts use more commonly.

The total offset method is easy to implement because it does not require the court to make specific predictions about the economy's future performance. The method was accurate from 1960 through 1980 because the inflating and discounting factors that prevailed during that period were roughly equal. Economic theory suggests that this relationship should continue in the future. $\mathrm{Ab}$ sent strong evidence that the inflating and discounting factors no longer offset each other, the total offset method should continue to produce accurate awards. Once derided as the product of a frontier state, the total offset method now deserves more widespread use.

Michael T. Brody 